\title{
Review \\ Combination of Drugs and Cell Transplantation: More Beneficial Stem Cell-Based Regenerative Therapies Targeting Neurological Disorders
}

\author{
Kaneyasu Nishimura *(D) and Kazuyuki Takata
}

check for updates

Citation: Nishimura, K.; Takata, K. Combination of Drugs and Cell Transplantation: More Beneficial Stem Cell-Based Regenerative Therapies Targeting Neurological Disorders. Int. J. Mol. Sci. 2021, 22, 9047. https:// doi.org/10.3390/ijms22169047

Academic Editor: Pavla Jendelova

Received: 12 July 2021

Accepted: 19 August 2021

Published: 22 August 2021

Publisher's Note: MDPI stays neutral with regard to jurisdictional claims in published maps and institutional affiliations.

Copyright: (c) 2021 by the authors. Licensee MDPI, Basel, Switzerland. This article is an open access article distributed under the terms and conditions of the Creative Commons Attribution (CC BY) license (https:// creativecommons.org/licenses/by/ $4.0 /)$.
Division of Integrated Pharmaceutical Science, Kyoto Pharmaceutical University, Kyoto 607-8414, Japan; kaz@mb.kyoto-phu.ac.jp

* Correspondence: k-nishimura@mb.kyoto-phu.ac.jp; Tel.: +81-75-595-4649

\begin{abstract}
Cell transplantation therapy using pluripotent/multipotent stem cells has gained attention as a novel therapeutic strategy for treating neurodegenerative diseases, including Parkinson's disease, Alzheimer's disease, Huntington's disease, ischemic stroke, and spinal cord injury. To fully realize the potential of cell transplantation therapy, new therapeutic options that increase cell engraftments must be developed, either through modifications to the grafted cells themselves or through changes in the microenvironment surrounding the grafted region. Together these developments could potentially restore lost neuronal function by better supporting grafted cells. In addition, drug administration can improve the outcome of cell transplantation therapy through better accessibility and delivery to the target region following cell transplantation. Here we introduce examples of drug repurposing approaches for more successful transplantation therapies based on preclinical experiments with clinically approved drugs. Drug repurposing is an advantageous drug development strategy because drugs that have already been clinically approved can be repurposed to treat other diseases faster and at lower cost. Therefore, drug repurposing is a reasonable approach to enhance the outcomes of cell transplantation therapies for neurological diseases. Ideal repurposing candidates would result in more efficient cell transplantation therapies and provide a new and beneficial therapeutic combination.
\end{abstract}

Keywords: cell transplantation therapy; drugs; combined therapy; neurodegenerative diseases; pluripotent stem cells; multipotent stem cells

\section{Introduction}

The central nervous system of adult humans is not innately repaired following the loss of neuronal cells due to neurological damage and diseases. Despite ongoing substantial efforts over many decades, successful therapies have not yet been established for several neuronal disorders, including Parkinson's disease (PD), Alzheimer's disease (AD), Huntington's disease (HD), ischemic stroke, and spinal cord injury (SCI). Current therapies include medications, surgical treatment, and rehabilitation, but these interventions can only help to manage the pathological symptoms of diseases and cannot restore lost neuronal function or ultimately provide cures. Therefore, although the currently available therapies may provide some symptomatic relief, existing therapeutic procedures neither slow disease progression nor repair damaged structures.

Recently, cell transplantation therapy has gained substantial attention as a novel therapeutic strategy in the treatment of neurological diseases. Pluripotent stem cells (PSCs), including embryonic stem cells (ESCs) and induced pluripotent stem cells (iPSCs), are promising sources of cell-based regenerative therapies because these cells give rise to defined cell types at necessary quantities and scalabilities [1,2]. Recent advantages in PSC technology include the ability to generate clinical-grade donor cells in the treatment of neurological diseases, including age-related macular degeneration (AMD), PD, HD, and 
SCI, in which lost neurons can be functionally repaired. Therapeutic benefits of iPSCs extend to autologous transplantation, as they may prevent negative immune responses such as immune rejection following cell grafting [3-6]. Numerous clinical and preclinical studies have shown that transplantation of dopaminergic (DA) progenitors, medium spiny neurons, and neural precursor cells (NPCs) are promising therapeutic strategies that could aid in the recovery of parkinsonian motor symptoms and motor function in HD and SCI, respectively. Several groups have established robust and scalable protocols to obtain donor cells from human PSCs (hPSCs), and they have demonstrated the efficacy and safety of grafted cells with long-term trials in animal models, including rodents and non-human primates [7-12]. These grafted cells can survive and resume their appropriate function in the nervous system by replacement of lost neuronal function.

Whilst cell-based regenerative medicine has substantial promise, significant challenges remain. Donor cells should meet criteria regarding safety, efficacy, stability, reproducibility, and scalability before transplantation into patients. Additionally, protocols surrounding good manufacturing practice-grade production should be developed using quality control tests at a facility dedicated to clinical trials. Cell grafts result in significant improvement in the quality of life for patients and their families. For this purpose, several steps should be taken to determine the efficacy of grafted cells, such as cell survival analyses, neuronal maturation, neurite extension to target cells, formation of synapses with target neurons, and functional integration into the host neural circuitry following cell transplantation [13].

Additionally, safety issues including immune rejection of grafted cells by neuroinflammation and tumorigenicity of the grafted cells following cell transplantation must be avoided to provide safer cell transplantation therapy to patients. To address these issues, some therapeutic options have already been developed, including monitoring inflammations and graft size by positron emission tomography imaging, inhibiting tumorigenicity and overgrowth of grafted cells by $\gamma$-ray irradiation, and finally surgically removing grafted cells when risks of cell transplantation outweighed the benefits [9,14-17].

The CNS has endogenous, but not sufficient, potential to compensate for lost neuronal functions by recruiting endogenous neural progenitors, suggesting that grafted-neural progenitors could also respond to their microenvironment [18-21]. The next step in improving outcomes after cell transplantation should be indirect modification of the microenvironment of the host-targeted region and grafted neurons. If drugs could be successfully targeted and delivered to grafted neurons, medications could be a powerful method for modifying brain microenvironments and preclude invasive surgical operations.

Together with the discovery of cell transplantation therapies, numerous efforts have also been made to inject or systemically administer certain compounds and soluble factors along with grafted cells. For this strategy, an initial aim should be to screen potential reagents from a group of non-approved drugs or materials that can modify the microenvironment of grafted cells, since it is necessary to establish the proof-of-concept for combination therapy of cell transplantation and drugs, and even the usage of non-approved drugs, as a first step. Next, researchers could focus on unrecognized side effects of alreadyapproved drugs on grafted cells as part of a drug repurposing approach. Drug repurposing is advantageous because effective and safe doses of drugs, as well as routes of administration, have already been established. Furthermore, details regarding their pharmacokinetics and contraindications for combined use are also known. Therefore, drug repurposing may provide a therapeutic opportunity that can treat patients more quickly and at a lower cost than new drug development. A combination of cell transplantation therapy and treatment with approved drugs may synergistically improve the outcome for neurological patients.

Here, we show proof-of-concept for conventional approaches with endogenous growth factors have been established and can improve the efficacy of cell transplantation therapy. Next, we discuss the therapeutic significance of repurposed drugs as a replacement for endogenous growth factors and how this may improve outcomes of cell transplantation therapy. We also highlight examples of preclinical studies using repurposed drugs that improve the efficacy of cell transplantation therapy for neurological diseases. Finally, we 
discuss current issues and future prospects of combination strategies of cell transplantation therapy and approved, repurposed drugs.

\section{Translational Approach of Endogenous Growth Factors for Effective Cell Transplantation Therapy}

Endogenous neurotrophic factors such as glial cell-derived neurotrophic factor (GDNF), brain-derived neurotrophic factor, and nerve growth factor are secreted from glial cells including astrocytes, oligodendrocytes, and microglia. These factors all play important roles in neural development, maturation, and survival during brain development [22]. Endogenous neurotrophic factors are expected to be able to help support grafted neuronal cells. For instance, GDNF is an endogenous soluble factor that exerts a potent effect on cell survival and the maturation of DA neurons by stimulating the GDNF receptor RET in cell culture systems and in animal models of PD. GDNF was examined to determine whether it could support grafted DA neurons and result in better outcomes following cell transplantation experiments, and results from an animal study indicated that GDNF increased the survival and maturation of grafted DA neurons [23-25]. These studies revealed that endogenous factors, which have protective effects both in vivo and in vitro, are translatable to cell transplantation. Although GDNF treatment moved to clinical trials, GDNF has since been withdrawn, as the anti-GDNF antibody was produced in the recipient patients [26]. Recent reports suggested that a novel small molecule, BT13, could bind to RET and activate its downstream signaling cascades [27]. BT13 protects DA neurons from neurotoxin-induced cell death in vitro. Additionally, BT13 activates DA signaling via RET and promotes the release of DA in the striatum in vivo, suggesting that BT13 is a candidate compound for PD therapy possibly applicable for successful cell engraftment and warranting further study [28].

\section{Drug Repurposing Approach toward Effective Cell Transplantation Therapy}

In order for more effective neuronal transplantation therapy, cell survival, neuronal maturation, neurite extension, and formation of synapses with host neurons are all necessary. To achieve these, therapeutic options in clinical and preclinical studies have included gene therapy, rehabilitation, and medication [29-32]. Medication is considered the most simple treatment option with regards to patient burden and avoids invasive surgical operations. Several drug candidates for repurposing could be applied as part of a combination strategy for cell transplantation therapy and pharmacotherapy to improve outcomes of cell transplantation therapy (Figure 1). For a combination strategy to work, drugs must be appropriately delivered to the grafted cells and manipulate the microenvironment of the grafting site. Potential examples of drug repurposing for more successful transplantation therapy are described below.

\subsection{Immunosuppressants}

For decades, immunosuppressant drugs such as cyclosporine A (CsA) and tacrolimus (TAC, also known as FK506) have been widely used to suppress the immune rejection of grafted tissues and cells in cases of allo- and xeno-transplantation. Recent clinical study suggested that immunosuppressant drugs were not needed for transplantation therapy using autologous iPSC-derived neurons [33]. However, it still needed to suppress the immune response in cases of allogenic transplantation using ESC- and allogenic iPSCderived neurons [34]. CsA suppresses the activation of lymphocytes by blocking interleukin (IL)-2 synthesis through inhibition of the calcineurin pathway [35]. CsA improved cell survival after human fetal DA neurons were grafted into a rat model of PD through a mechanism that blocked the activation of immune cells [36-38]. Based on these preclinical studies, CsA was administered to PD patients who received human fetal tissue in order to minimize the risk of immune rejection [39-42]. Based on this experimental and clinical evidence, CsA is now widely used to improve the survival of grafted PSC-derived neurons in cross-species studies by systemic administration in various neurological disease animal models including PD, SCI, HD, retinal degeneration, and stroke [8,43-50]. 


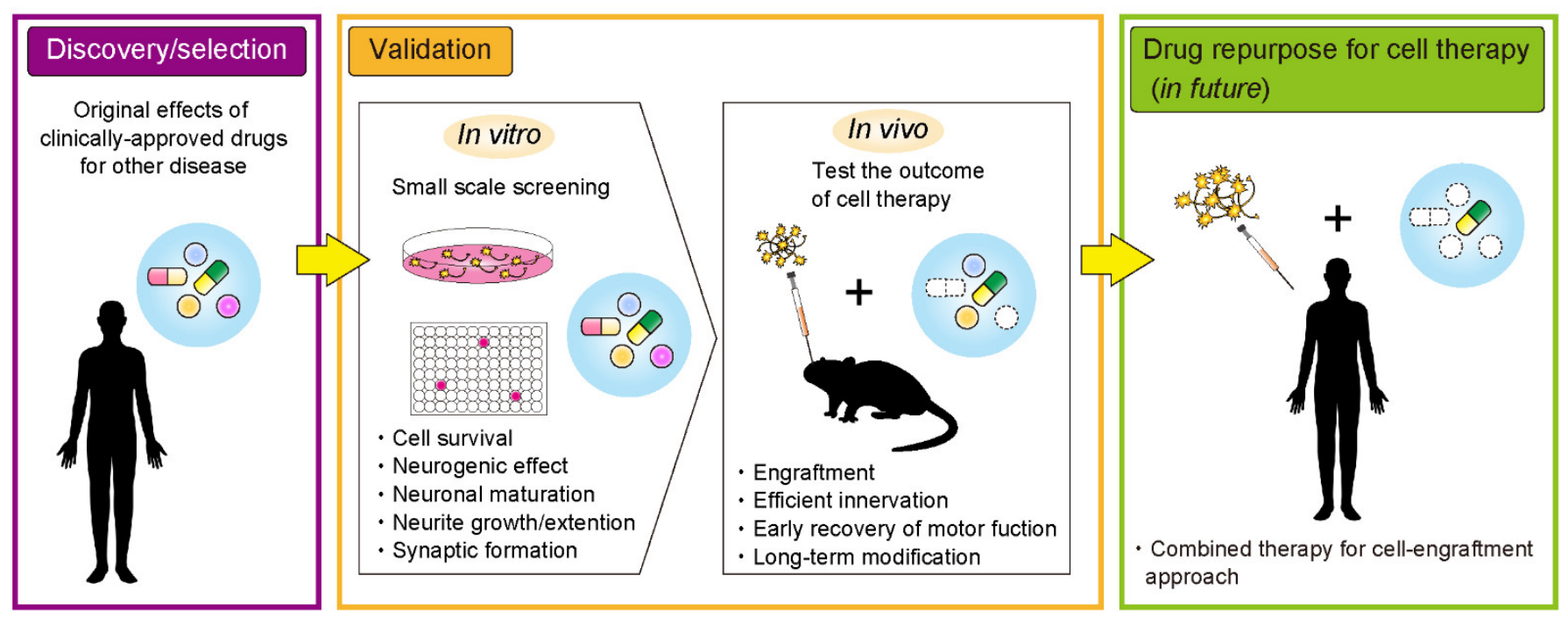

Figure 1. An overview of the drug repurposing process towards more effective cell transplantation therapy for neurological diseases.

TAC binds the FK506 binding protein (FKBP) and blocks IL-2 production through inhibition of the peptidylprolyl cis-trans isomerase activity of FKBP [51]. TAC exerts a highly potent immunosuppressive effect at concentrations 100-fold lower than CsA [52,53]. TAC is also used for increasing the survival of grafted PSC-derived neural progenitors/organoids in cross-species studies in various neurological disease models $[9,12,54,55]$. Additionally, recent reports have shown that TAC suppressed the infiltration of lymphocytes into the graft area of hiPSC-derived cells in a major histocompatibility complex-matched/mismatched monkey study $[4,55]$. Therefore, immunosuppressive reagents are the most promising drugs to support the survival of grafted neurons.

\subsection{Rho-Kinase Inhibitors}

The targeted inhibition of Rho-kinase with Y-27632 drastically improved the survival of undifferentiated hPSCs and the proliferative ability of single-cell-passaged cells [29]. The major issue after cell transplantation is cell death as a result of mechanical stress and the loss of cell-cell contacts due to cell dissociation, low levels of trophic factors, and oxidative stress and hypoxia $[56,57]$. When mouse ESC-derived neurospheres were grafted into a mouse brain together with Y-27632, cell survival significantly improved as a result of fewer apoptotic cells in the graft [58]. Additionally, Y-27632 was also reported to promote neurite growth in rat NPCs [59], human NPC culture [60], and axonal regeneration in a cat model of optic nerve injury [61]. Therefore, Rho-kinase inhibitors are potent therapies that may increase cell survival and neurite extension and ultimately help in the recovery of neuronal function following cell transplantation.

\subsection{Chondroitinase $A B C(C h A B C)$}

Chondroitin sulfate proteoglycans (CSPGs) are widely expressed in the CNS where they are involved in cell adhesion and growth, receptor binding, and cell migration during development [62]. In response to neuronal injury and disease, astrocytes accumulate at the injured region and secrete CSPGs to form a glial scar, which is a biological barrier that inhibits axonal extension. Glial scars result in failures in neurite extension and regeneration during endogenous repair following injury and disease [63]. After cell transplantation therapy, a glial scar forms and surrounds the grafted cells to inhibit neurite growth and regeneration from the grafted cells and disturbs the appropriate neuronal innervation of the grafted neurons with host neurons. ChABC is an enzyme clinically used in patients with lumbar disc herniation that cleaves the sulfated glycosaminoglycan chain of CSPGs and promotes additional axonal regeneration in the scarred region [64]. A preclinical study 
on SCI treatment demonstrated that $\mathrm{ChABC}$ promotes axonal regrowth by modifying the plasticity of myelinated tracts $[65,66]$. Because cell transplantation is an invasive procedure that evokes local accumulations of astrocytes and microglia, as well as inflammation, glial scars form along the grafted site. One benefit of cell transplantation is the ability of grafted neurons to promote axonal innervation of host neurons following cell transplantation to restore lost neuronal functions. Based on this observation, several groups have examined the ability of ChABC in some types of neuronal cells to increase neurite extension and integration of grafted cells into the host neural circuitry. It was shown that $\mathrm{ChABC}$, when injected into the medial forebrain bundle, cleaved CSPGs along the nigrostriatal pathway and promoted the reinnervation of grafted DA neurons into the striatum in an animal model of PD [67]. In cell transplantation therapy for SCI with either hiPSC-derived NPCs or hiPSC-derived neuroepithelial cells, ChABC promotes tissue repair and cell survival with long-term functional recovery of motor activity $[68,69]$.

\subsection{Valproic Acid (VPA)}

VPA is used clinically for long-term treatment of epilepsy and mood disorders. VPA has been reported to inhibit histone deacetylases, leading to hyperacetylation of histones, in addition to mediating the neuronal differentiation of adult hippocampal neural progenitors [70]. VPA also induced an increase in neuronal gene expression during the differentiation of hESCs into neurons [71]. An in vivo study using an SCI rat model demonstrated that VPA administration enhanced the neurogenic potential of neural stem/precursor cells after SCI and gene expression of neuronal markers around the injured spinal cord. Motor function also recovered as a result of VPA administration following SCI [72]. Taken together, VPA administration is expected to increase the neurogenic potential of neural stem/precursor cells following neuronal injury in addition to promoting functional recovery following cell transplantation for neuronal injury. Previous reports have shown that VPA administration enhanced the restoration of hindlimb function when mouse neural stem cells were transplanted together with VPA in a mouse model of SCI. According to a histological analysis, VPA administration promoted neuronal differentiation rather than glial differentiation [73]. When neonatal $\mathrm{Nrl}^{+}$retinal cells were grafted with VPA into the eyes of rd mice, which have a phosphodiesterase $6 \mathrm{~b}$ gene mutation and exhibit rapid degeneration of retinal cells, the number of integrated cells into the eye increased following VPA supplementation. Further, an increased number of rhodopsin ${ }^{+}$cells was also observed in the early treatment period [74]. VPA administration increased the number of $\mathrm{NeuN}^{+}$ neurons and tyrosine hydroxylase $(\mathrm{TH})^{+} \mathrm{DA}$ neurons in the grafts of mouse iPSC-derived DA progenitors and increased the number of DA neurons transplanted into the striatum of normal mouse [75]. These reports suggest that both systemic administration and local injection of VPA potentiate neuronal differentiation of grafted-neural cells.

\subsection{Zonisamide}

Zonisamide is widely used as an anti-epilepsy and anti-parkinsonian drug. Recent findings have shown that zonisamide has neuroprotective and neuroregenerative effects in cases of neurological injury. Further, recent studies demonstrated that zonisamide rescued the loss of DA neurons following 1-methyl-4-phenyl-1,2,3,6-tetrahydropyridine treatmentinduced toxicity in parkinsonian animal models by activating tyrosine hydroxylase activity through the inhibition of monoamine oxidase B $[76,77]$. An additional report suggested that the inhibition of microglial activation by zonisamide mediates the survival of DA neurons [78]. Electrophysiological analysis revealed that zonisamide protects striatal neurons against rotenone-induced mitochondrial impairment [79]. Zonisamide also exerts a protective effect against oxidative stress-induced cell death of primary motor neurons and enhances neurite elongation and regeneration via an increase in nerve growth factors. In a mouse model in which a sciatic nerve autograft was used, zonisamide improved the sciatic functional index, which served as a marker of hindlimb motor functional recovery after sciatic nerve autograft procedures were performed [80]. Repeated administration 
of zonisamide enhanced the number of surviving mouse iPSC-derived DA neurons following cell transplantation into the mouse striatum [75]. Long-term daily administration of zonisamide also promoted the survival of grafted hiPSC-derived DA neurons in 6hydroxydopamine (6-OHDA)-lesioned rat striatum via the activation of SLIT and NTRK like protein 6; these proteins are expressed in the striatum, which was the target region of cell transplantation [81].

\section{6. $17 \beta$-Estradiol (E2)}

E2 is a gonadal steroid hormone and an essential female sex hormone. Clinically, E2 and its derivative, estradiol-2-benzoate (E2B), are used to reduce menopausal and age-related symptoms in women. E2 has been reported to exert protective effects against neurotoxic reagents and oxidative stress in cell culture systems [82,83]. Administration of E2 to MPTP-treated parkinsonian rodent models exhibited protective effects against neuronal death by inhibiting oxidative stress and inflammation, and a low dose of E2 administered to rats with SCI resulted in improved motor function by decreasing inflammation, tissue damage, gliosis, and neuronal cell death [84-87]. Therefore E2, when combined with cells, could be applicable for cell transplantation therapy in SCI. Recently, several studies have reported on the combination therapy of E2 and transplantation of Schwann cells for the treatment of SCI in animal models [88-90]. Additionally, it has been reported that systemic and repeated administration of E2B affects the activation of integrin $\alpha 5$, which is selectively expressed in striatal medium spiny neurons innervated by DA neurons in adult female rodents [91]. Integrin $\alpha 5$ can be activated through upregulation of the reelin pathway, and because integrin $\alpha 5 \beta 1$ has a high affinity for fibronectin, cell-cell interactions between striatal neurons and hiPSC-derived DA neurons could be facilitated by the activation of integrin $\alpha 5 \beta 1[92,93]$. Systemic administration of E2B to 6-OHDA-lesioned parkinsonian rats promoted synaptic input to the host striatal neurons from the grafted iPSC-derived DA neurons and resulted in earlier recovery of motor function. Additionally, levels of integrin $\alpha 5$ transcripts in the postmortem putamen of PD patients were the same as those of healthy controls. Together these findings suggest that E2B is a drug that can potentially support cell transplantation therapy.

\section{Future Prospects}

In this review, we introduced an overview of drug repurposing approaches to emphasize its potential role in cell transplantation therapies for treatment of neurological diseases. Current drug repurposing approaches have identified candidate drugs through pharmacotherapy for other diseases, coincidences, or bioinformatic approaches from accumulated clinical cases [94,95]. The number of cases of cell transplantation therapy using pluripotent or multipotent stem cells remains low, as it is a developing treatment approach with clinical trials ongoing worldwide [96,97]. Because of these reasons, the number of patients who have received both cell transplantation and pharmacotherapy is not sufficient for identifying new and successful drug(s) for drug repositioning. Therefore, minimal opportunities exist for determining new combinations of conventional drugs to increase the therapeutic benefit of cell transplantation. However, numerous preclinical studies are underway to establish the proof-of-concept that clinically approved drugs can support the outcome of cell transplantation therapy. Recent progress has used clinical-grade donor cells-derived from hPSCs in transplantation experiments using animal models $[5,7,10,98]$. In the future, more preclinical and clinical cases will contribute to the search for new candidate drugs that support cell transplantation therapy.

On the other hand, issues have been raised that question the efficacy and safety of drug repurposing to support cell transplantation therapy. For instance, some already-approved drugs, especially non-CNS drugs, are unable to cross the blood brain barrier and are difficult to reach the CNS. Additionally, transcellular transporters such as the ATP binding cassette $(A B C)$ transporter expressed in brain endothelial cells limit the efficacy of any drug treatment by controlling penetration and excretion of the drugs [98]. Therefore, the 
administration route and drug delivery approach must be considered for CNS targeting if repurposed drug(s) are not developed as CNS drugs. The appropriate dose, administration period, and dosing frequency for cell transplantation therapy will also need to be reoptimized for each drug, since current administration conditions are used in the context of other diseases. Another limitation of drug repurposing is that aging is a non-modifiable risk factor for $\mathrm{AD}, \mathrm{PD}$, and stroke. If repurposed drugs are not originally for use in elderly individuals, pharmacokinetics and pharmacodynamics of repurposed drugs will need to be considered to determine optimal administration $[99,100]$. Additionally, unexpected side effects should be expected by combining repurposed drugs with cell transplantation therapy. The safety profiles of repurposed drugs will need to be optimized for use in cell transplantation therapy. The results of current candidates are only suggestions from preclinical studies and more data must be accumulated before clinical trials are conducted with these candidates. Bioinformatic approaches in particular could help develop useful prediction tools to identify additional candidate drugs in the future. Bioinformatic tools can predict and evaluate biological significance, experimental and clinical data, and chemical structure of candidates $[95,101]$.

\section{Conclusions}

In this review, we highlighted several potential candidate drugs that can be used for more effective cell transplantation therapy of neurological diseases. These candidate drugs were selected from preclinical studies that demonstrated the effective combination of cell transplantation therapy with repurposed drugs. More clinical cases should be studied to identify additional repurposed drugs. We expect that a novel combination therapy consisting of cells and drugs would benefit patients as a next-generation approach, as new stem cell-based regenerative therapies are also being developed. Drug repurposing may become a beneficial approach for combination therapy of cell transplantation and pharmacotherapy and may lead to better outcomes of stem cell-based regenerative medicine.

Funding: The study was supported by grants-in-aids from the Kyoto Pharmaceutical University Fund for the Promotion of Scientific Research (K.N.), the Hoansha Foundation (K.T.) and the Smoking Research Foundation (K.T.) and the Japan Society for the Promotion of Science (JSPS) KAKEN (19K07854 to K.N. and 20H03569 to K.T.).

Conflicts of Interest: The authors declare no conflict of interest.

\section{References}

1. Thomson, J.A.; Itskovitz-Eldor, J.; Shapiro, S.S.; Waknitz, M.A.; Swiergiel, J.J.; Marshall, V.S.; Jones, J.M. Embryonic stem cell lines derived from human blastocysts. Science 1998, 282, 1145-1147. [CrossRef] [PubMed]

2. Takahashi, K.; Tanabe, K.; Ohnuki, M.; Narita, M.; Ichisaka, T.; Tomoda, K.; Yamanaka, S. Induction of pluripotent stem cells from adult human fibroblasts by defined factors. Cell 2007, 131, 861-872. [CrossRef]

3. Mandai, M.; Watanabe, A.; Kurimoto, Y.; Hirami, Y.; Morinaga, C.; Daimon, T.; Fujihara, M.; Akimaru, H.; Sakai, N.; Shibata, Y.; et al. Autologous induced stem-cell-derived retinal cells for macular degeneration. N. Engl. J. Med. 2017, 376, 1038-1046. [CrossRef]

4. Morizane, A.; Kikuchi, T.; Hayashi, T.; Mizuma, H.; Takara, S.; Doi, H.; Mawatari, A.; Glasser, M.F.; Shiina, T.; Ishigaki, H.; et al. MHC matching improves engraftment of iPSC-derived neurons in non-human primates. Nat. Commun. 2017, 8, 385. [CrossRef] [PubMed]

5. Song, B.; Cha, Y.; Ko, S.; Jeon, J.; Lee, N.; Seo, H.; Park, K.; Lee, I.; Lopes, C.; Feitosa, M.; et al. Human autologous iPSC-derived dopaminergic progenitors restore motor function in Parkinson's disease models. J. Clin. Investig. 2020, 130, 904-920. [CrossRef] [PubMed]

6. Osborn, T.M.; Hallett, P.J.; Schumacher, J.M.; Isacson, O. Advantages and recent developments of autologous cell therapy for Parkinson's disease patients. Front. Cell. Neurosci. 2020, 14, 58. [CrossRef] [PubMed]

7. Kamao, H.; Mandai, M.; Okamoto, S.; Sakai, N.; Suga, A.; Sugita, S.; Kiryu, J.; Takahashi, M. Characterization of human induced pluripotent stem cell-derived retinal pigment epithelium cell sheets aiming for clinical application. Stem Cell Rep. 2014, 2, 205-218. [CrossRef]

8. Kobayashi, Y.; Okada, Y.; Itakura, G.; Iwai, H.; Nishimura, S.; Yasuda, A.; Nori, S.; Hikishima, K.; Konomi, T.; Fujiyoshi, K.; et al. Pre-evaluated safe human iPSC-derived neural stem cells promote functional recovery after spinal cord injury in common marmoset without tumorigenicity. PLoS ONE 2012, 7, e52787. [CrossRef] 
9. Kikuchi, T.; Morizane, A.; Doi, D.; Magotani, H.; Onoe, H.; Hayashi, T.; Mizuma, H.; Takara, S.; Takahashi, R.; Inoue, H.; et al. Human iPS cell-derived dopaminergic neurons function in a primate Parkinson's disease model. Nature 2017, 548, 592-596. [CrossRef] [PubMed]

10. Piao, J.; Zabierowski, S.; Dubose, B.N.; Hill, E.J.; Navare, M.; Claros, N.; Rosen, S.; Ramnarine, K.; Horn, C.; Fredrickson, C.; et al. Preclinical efficacy and safety of a human embryonic stem cell-derived midbrain dopamine progenitor product, MSK-DA01. Cell Stem Cell 2021, 28, 217-229. [CrossRef]

11. Nicoleau, C.; Viegas, P.; Peschanski, M.; Perrier, A.L. Human pluripotent stem cell therapy for Huntington's disease: Technical, immunological, and safety challenges. Neurotherapeutics 2011, 8, 562-576. [CrossRef]

12. Iwai, H.; Shimada, H.; Nishimura, S.; Kobayashi, Y.; Itakura, G.; Hori, K.; Hikishima, K.; Ebise, H.; Negishi, N.; Shibata, S.; et al. Allogeneic neural stem/progenitor cells derived from embryonic stem cells promote functional recovery after transplantation into injured spinal cord of nonhuman primates. Stem Cells Transl. Med. 2015, 4, 708-719. [CrossRef] [PubMed]

13. Nishimura, K.; Takahashi, J. Drug discovery toward successful cell transplantation therapy for Parkinson's disease using human pluripotent stem cells. Adv. Regen. Biol. 2016, 3, 31772. [CrossRef]

14. Katsukawa, M.; Nakajima, Y.; Fukumoto, A.; Doi, D.; Takahashi, J. Fail-safe therapy by gamma-ray irradiation against tumor formation by human-induced pluripotent stem cell-derived neural progenitors. Stem Cells Dev. 2016, 25, 815-825. [CrossRef] [PubMed]

15. Tanimoto, Y.; Yamasaki, T.; Nagoshi, N.; Nishiyama, Y.; Nori, S.; Nishimura, S.; Iida, T.; Ozaki, M.; Tsuji, O.; Ji, B.; et al In vivo monitoring of remnant undifferentiated neural cells following human induced pluripotent stem cell-derived neural stem/progenitor cells transplantation. Stem Cells Transl. Med. 2020, 9, 465-477. [CrossRef]

16. Lan, M.L.; Acharya, M.M.; Tran, K.K.; Bahari-Kashani, J.; Patel, N.H.; Strnadel, J.; Giedzinski, E.; Limoli, C.L. Characterizing the radioresponse of pluripotent and multipotent human stem cells. PLoS ONE 2012, 7, e50048. [CrossRef]

17. Zhang, H.; Song, F.; Xu, C.; Liu, H.; Wang, Z.; Li, J.; Wu, S.; Shen, Y.; Chen, Y.; Zhu, Y.; et al. Spatiotemporal PET imaging of dynamic metabolic changes after therapeutic approaches of induced pluripotent stem cells, neuronal stem cells, and a Chinese patent medicine in stroke. J. Nucl. Med. 2015, 56, 1774-1779. [CrossRef]

18. Nishimura, K.; Murayama, S.; Takahashi, J. Identification of neurexophilin 3 as a novel supportive factor for survival of induced pluripotent stem cell-derived dopaminergic progenitors. Stem Cells Transl. Med. 2015, 4, 932-944. [CrossRef] [PubMed]

19. Ohira, K.; Furuta, T.; Hioki, H.; Nakamura, K.C.; Kuramoto, E.; Tanaka, Y.; Funatsu, N.; Shimizu, K.; Oishi, T.; Hayashi, M.; et al. Ischemia-induced neurogenesis of neocortical layer 1 progenitor cells. Nat. Neurosci. 2010, 13, 173-179. [CrossRef]

20. Höglinger, G.U.; Rizk, P.; Muriel, M.P.; Duyckaerts, C.; Oertel, W.H.; Caille, I.; Hirsch, E.C. Dopamine depletion impairs precursor cell proliferation in Parkinson disease. Nat. Neurosci. 2004, 7, 726-735. [CrossRef] [PubMed]

21. Arvidsson, A.; Collin, T.; Kirik, D.; Kokaia, Z.; Lindvall, O. Neuronal replacement from endogenous precursors in the adult brain after stroke. Nat. Med. 2002, 8, 963-970. [CrossRef]

22. Pöyhönen, S.; Er, S.; Domanskyi, A.; Airavaara, M. Effects of neurotrophic factors in glial cells in the central nervous system: Expression and properties in neurodegeneration and injury. Front. Physiol. 2019, 10, 1-20. [CrossRef]

23. Apostolides, C.; Sanford, E.; Hong, M.; Mendez, I. Glial cell line-derived neurotrophic factor improves intrastriatal graft survival of stored dopaminergic cells. Neuroscience 1998, 83, 363-372. [CrossRef]

24. Thompson, L.H.; Grealish, S.; Kirik, D.; Björklund, A. Reconstruction of the nigrostriatal dopamine pathway in the adult mouse brain. Eur. J. Neurosci. 2009, 30, 625-638. [CrossRef]

25. Kirik, D.; Cederfjäll, E.; Halliday, G.; Petersén, Å. Gene therapy for Parkinson's disease: Disease modification by GDNF family of ligands. Neurobiol. Dis. 2017, 97, 179-188. [CrossRef]

26. Tatarewicz, S.M.; Wei, X.; Gupta, S.; Masterman, D.; Swanson, S.J.; Moxness, M.S. Development of a maturing T-cell-mediated immune response in patients with idiopathic Parkinson's disease receiving r-metHuGDNF via continuous intraputaminal infusion. J. Clin. Immunol. 2007, 27, 620-627. [CrossRef]

27. Sidorova, Y.A.; Bespalov, M.M.; Wong, A.W.; Kambur, O.; Jokinen, V.; Lilius, T.O.; Suleymanova, I.; Karelson, G.; Rauhala, P.V.; Karelson, M.; et al. A novel small molecule GDNF receptor RET agonist, BT13, promotes neurite growth from sensory neurons in vitro and attenuates experimental neuropathy in the rat. Front. Pharmacol. 2017, 8, 365. [CrossRef]

28. Mahato, A.K.; Kopra, J.; Renko, J.M.; Visnapuu, T.; Korhonen, I.; Pulkkinen, N.; Bespalov, M.M.; Domanskyi, A.; Ronken, E.; Piepponen, T.P.; et al. Glial cell line-derived neurotrophic factor receptor rearranged during transfection agonist supports dopamine neurons in vitro and enhances dopamine release in vivo. Mov. Disord. 2020, 35, 245-255. [CrossRef] [PubMed]

29. Watanabe, K.; Ueno, M.; Kamiya, D.; Nishiyama, A.; Matsumura, M.; Wataya, T.; Takahashi, J.B.; Nishikawa, S.; Nishikawa, S.I.; Muguruma, K.; et al. A ROCK inhibitor permits survival of dissociated human embryonic stem cells. Nat. Biotechnol. 2007, 25, 681-686. [CrossRef] [PubMed]

30. Ross, H.H.; Ambrosio, F.; Trumbower, R.D.; Reier, P.J.; Behrman, A.L.; Wolf, S.L. Neural stem cell therapy and rehabilitation in the central nervous system: Emerging partnerships. Phys. Ther. 2016, 96, 734-742. [CrossRef] [PubMed]

31. Shimogawa, T.; Sakaguchi, H.; Kikuchi, T.; Tsuchimochi, R.; Sano, N.; Torikoshi, S.; Ito, A.; Aoyama, T.; Iihara, K.; Takahashi, J. Therapeutic effects of combined cell transplantation and locomotor training in rats with brain injury. NPJ Regen. Med. 2019, 4, 1-8. [CrossRef] 
32. Gantner, C.W.; de Luzy, I.R.; Kauhausen, J.A.; Moriarty, N.; Niclis, J.C.; Bye, C.R.; Penna, V.; Hunt, C.P.J.; Ermine, C.M.; Pouton, C.W.; et al. Viral delivery of GDNF promotes functional integration of human stem cell grafts in Parkinson's disease. Cell Stem Cell 2020, 26, 511-526. [CrossRef]

33. Schweitzer, J.S.; Song, B.; Herrington, T.M.; Park, T.-Y.; Lee, N.; Ko, S.; Jeon, J.; Cha, Y.; Kim, K.; Li, Q.; et al. Personalized iPSC-derived dopamine progenitor cells for Parkinson's disease. N. Engl. J. Med. 2020, 382, 1926-1932. [CrossRef] [PubMed]

34. Barker, R.A.; Parmar, M.; Studer, L.; Takahashi, J. Human trials of stem cell-derived dopamine neurons for Parkinson's disease: Dawn of a new era. Cell Stem Cell 2017, 21, 569-573. [CrossRef] [PubMed]

35. Clipstone, N.A.; Crabtree, G.R. Identification of calcineurin as a key signalling enzyme in T-lymphocyte activation. Nature 1992, 357, 695-697. [CrossRef]

36. Strömberg, I.; Bygdeman, M.; Goldstein, M.; Seiger, Å.; Olson, L. Human fetal substantia nigra grafted to the dopaminedenervated striatum of immunosuppressed rats: Evidence for functional reinnervation. Neurosci. Lett. 1986, 71, 271-276. [CrossRef]

37. Brundin, P.; Strecker, R.E.; Widner, H.; Clarke, D.J.; Nilsson, O.G.; Åstedt, B.; Lindvall, O.; Björklund, A. Human fetal dopamine neurons grafted in a rat model of Parkinson's disease: Immunological aspects, spontaneous and drug-induced behaviour, and dopamine release. Exp. Brain Res. 1988, 70, 192-208. [CrossRef]

38. Howard, M.A.; Dacey, R.G.; Winn, H.R. Brain xenografts: The effect of cyclosporin A on graft survival. J. Neurosurg. 1988, 69, 121-126. [CrossRef] [PubMed]

39. Lindvall, O.; Rehncrona, S.; Brundin, P.; Gustavii, B.; Åstedt, B.; Widner, H.; Lindholm, T.; Bjorklund, A.; Leenders, K.L.; Rothwell, J.C.; et al. Human fetal dopamine neurons grafted into the striatum in two patients with severe parkinson's disease: A detailed account of methodology and a 6-month follow-up. Arch. Neurol. 1989, 46, 615-631. [CrossRef]

40. Freed, C.R.; Breeze, R.E.; Rosenberg, N.L.; Schneck, S.A.; Kriek, E.; Qi, J.; Lone, T.; Zhang, Y.; Snyder, J.A.; Wells, T.H.; et al. Survival of implanted fetal dopamine cells and neurologic improvement 12 to 46 months after transplantation for Parkinson's disease. N. Engl. J. Med. 1992, 327, 1549-1555. [CrossRef]

41. Spencer, D.D.; Robbins, R.J.; Naftolin, F.; Marek, K.L.; Vollmer, T.; Leranth, C.; Roth, R.H.; Price, L.H.; Gjedde, A.; Bunney, B.S.; et al. Unilateral transplantation of human fetal mesencephalic tissue into the caudate nucleus of patients with Parkinson's disease. N. Engl. J. Med. 1992, 327, 1541-1548. [CrossRef] [PubMed]

42. Hoffer, B.J.; Leenders, K.L.; Young, D.; Gerhardt, G.; Zerbe, G.O.; Bygdeman, M.; Seiger, Å.; Olson, L.; Strömberg, I.; Freedman, R. Eighteen-month course of two patients with grafts of fetal dopamine neurons for severe Parkinson's disease. Exp. Neurol. 1992, 118, 243-252. [CrossRef]

43. Kriks, S.; Shim, J.W.; Piao, J.; Ganat, Y.M.; Wakeman, D.R.; Xie, Z.; Carrillo-Reid, L.; Auyeung, G.; Antonacci, C.; Buch, A.; et al. Dopamine neurons derived from human ES cells efficiently engraft in animal models of Parkinson's disease. Nature 2011, 480, 547-551. [CrossRef]

44. Kirkeby, A.; Grealish, S.; Wolf, D.A.; Nelander, J.; Wood, J.; Lundblad, M.; Lindvall, O.; Parmar, M. Generation of regionally specified neural progenitors and functional neurons from human embryonic stem cells under defined conditions. Cell Rep. 2012, 1, 703-714. [CrossRef]

45. Sundberg, M.; Bogetofte, H.; Lawson, T.; Jansson, J.; Smith, G.; Astradsson, A.; Moore, M.; Osborn, T.; Cooper, O.; Spealman, R.; et al. Improved cell therapy protocols for Parkinson's disease based on differentiation efficiency and safety of hESC-, hiPSC-, and non-human primate iPSC-derived dopaminergic neurons. Stem Cells 2013, 31, 1548-1562. [CrossRef] [PubMed]

46. Samata, B.; Kikuchi, T.; Miyawaki, Y.; Morizane, A.; Mashimo, T.; Nakagawa, M.; Okita, K.; Takahashi, J. X-linked severe combined immunodeficiency (X-SCID) rats for xeno-transplantation and behavioral evaluation. J. Neurosci. Methods 2015, 243, 68-77. [CrossRef]

47. Adler, A.F.; Cardoso, T.; Nolbrant, S.; Mattsson, B.; Hoban, D.B.; Jarl, U.; Wahlestedt, J.N.; Grealish, S.; Björklund, A.; Parmar, M. hESC-derived dopaminergic transplants integrate into basal ganglia circuitry in a preclinical model of Parkinson's disease. Cell Rep. 2019, 28, 3462-3473. [CrossRef] [PubMed]

48. Yoon, Y.; Kim, H.S.; Hong, C.P.; Li, E.; Jeon, I.; Park, H.J.; Lee, N.; Pei, Z.; Song, J. Neural transplants from human induced pluripotent stem cells rescue the pathology and behavioral defects in a rodent model of Huntington's disease. Front. Neurosci. 2020, 14, 558204. [CrossRef] [PubMed]

49. Tornero, D.; Wattananit, S.; Madsen, M.G.; Koch, P.; Wood, J.; Tatarishvili, J.; Mine, Y.; Ge, R.; Monni, E.; Devaraju, K.; et al. Human induced pluripotent stem cell-derived cortical neurons integrate in stroke-injured cortex and improve functional recovery. Brain 2013, 136, 3561-3577. [CrossRef] [PubMed]

50. Shirai, H.; Mandai, M.; Matsushita, K.; Kuwahara, A.; Yonemura, S.; Nakano, T.; Assawachananont, J.; Kimura, T.; Saito, K.; Terasaki, H.; et al. Transplantation of human embryonic stem cell-derived retinal tissue in two primate models of retinal degeneration. Proc. Natl. Acad. Sci. USA 2016, 113, E81-E90. [CrossRef] [PubMed]

51. Moore, J.M.; Peattie, D.A.; Fitzgibbon, M.J.; Thomson, J.A. Solution structure of the major binding protein for the immunosuppressant FK506. Nature 1991, 351, 248-250. [CrossRef] [PubMed]

52. Thomson, A.W. FK-506-How much potential? Immunol. Today 1989, 10, 6-9. [CrossRef] 
53. Maki, N.; Sekiguchi, F.; Nishimaki, J.; Miwa, K.; Hayano, T.; Takahashi, N.; Suzuki, M. Complementary DNA encoding the human T-cell FK506-binding protein, a peptidylprolyl cis-trans isomerase distinct from cyclophilin. Proc. Natl. Acad. Sci. USA 1990, 87, 5440-5443. [CrossRef] [PubMed]

54. Li, K.; Javed, E.; Scura, D.; Hala, T.J.; Seetharam, S.; Falnikar, A.; Richard, J.P.; Chorath, A.; Maragakis, N.J.; Wright, M.C.; et al. Human iPS cell-derived astrocyte transplants preserve respiratory function after spinal cord injury. Exp. Neurol. 2015, 271, 479-492. [CrossRef]

55. Kitahara, T.; Sakaguchi, H.; Morizane, A.; Kikuchi, T.; Miyamoto, S.; Takahashi, J. Axonal extensions along corticospinal tracts from transplanted human cerebral organoids. Stem Cell Rep. 2020, 15, 467-481. [CrossRef] [PubMed]

56. Meredith, J.E.; Fazeli, B.; Schwartz, M.A. The extracellular matrix as a cell survival factor. Mol. Biol. Cell 1993, 4, 953-961. [CrossRef]

57. Sortwell, C.E.; Pitzer, M.R.; Collier, T.J. Time course of apoptotic cell death within mesencephalic cell suspension grafts: Implications for improving grafted dopamine neuron survival. Exp. Neurol. 2000, 165, 268-277. [CrossRef] [PubMed]

58. Koyanagi, M.; Takahashi, J.; Arakawa, Y.; Doi, D.; Fukuda, H.; Hayashi, H.; Narumiya, S. Nobuo Hashimoto Inhibition of the Rho/ROCK pathway reduces apoptosis during transplantation of embryonic stem cell-derived neural precursors. J. Neurosci. Res. 2007, 3253, 3244-3253. [CrossRef]

59. Boomkamp, S.D.; Riehle, M.O.; Wood, J.; Olson, M.F.; Barnett, S.C. The development of a rat in vitro model of spinal cord injury demonstrating the additive effects of rho and ROCK inhibitors on neurite outgrowth and myelination. Glia 2012, 60, 441-456 [CrossRef]

60. Novozhilova, E.; Englund-Johansson, U.; Kale, A.; Jiao, Y.; Olivius, P. Effects of ROCK inhibitor Y27632 and EGFR inhibitor PD168393 on human neural precursors co-cultured with rat auditory brainstem explant. Neuroscience 2015, 287, 43-54. [CrossRef]

61. Ichikawa, M.; Yoshida, J.; Saito, K.; Sagawa, H.; Tokita, Y.; Watanabe, M. Differential effects of two ROCK inhibitors, Fasudil and Y-27632, on optic nerve regeneration in adult cats. Brain Res. 2008, 1201, 23-33. [CrossRef]

62. Laabs, T.; Carulli, D.; Geller, H.M.; Fawcett, J.W. Chondroitin sulfate proteoglycans in neural development and regeneration. Curr. Opin. Neurobiol. 2005, 15, 116-120. [CrossRef] [PubMed]

63. Silver, J.; Miller, J.H. Regeneration beyond the glial scar. Nat. Rev. Neurosci. 2004, 5, 146-156. [CrossRef]

64. Matsuyama, Y.; Chiba, K.; Iwata, H.; Seo, T.; Toyama, Y. A multicenter, randomized, double-blind, dose-finding study of condoliase in patients with lumbar disc herniation. J. Neurosurg. Spine 2018, 28, 499-511. [CrossRef]

65. Bukhari, N.; Torres, L.; Robinson, J.K.; Tsirka, S.E. Axonal regrowth after spinal cord injury via chondroitinase and the tissue plasminogen activator (tPA)/plasmin system. J. Neurosci. 2011, 31, 14931-14943. [CrossRef] [PubMed]

66. Alilain, W.J.; Horn, K.P.; Hu, H.; Dick, T.E.; Silver, J. Functional regeneration of respiratory pathways after spinal cord injury. Nature 2011, 475, 196-200. [CrossRef] [PubMed]

67. Kauhausen, J.A.; Thompson, L.H.; Parish, C.L. Chondroitinase improves midbrain pathway reconstruction by transplanted dopamine progenitors in Parkinsonian mice. Mol. Cell. Neurosci. 2015, 69, 22-29. [CrossRef]

68. Nori, S.; Khazaei, M.; Ahuja, C.S.; Yokota, K.; Ahlfors, J.E.; Liu, Y.; Wang, J.; Shibata, S.; Chio, J.; Hettiaratchi, M.H.; et al. Oligodendrogenic neural progenitor cells delivered with chondroitinase ABC facilitate functional repair of chronic spinal cord injury. Stem Cell Rep. 2018, 11, 1433-1448. [CrossRef]

69. Führmann, T.; Anandakumaran, P.N.; Payne, S.L.; Pakulska, M.M.; Varga, B.V.; Nagy, A.; Tator, C.; Shoichet, M.S. Combined delivery of chondroitinase $\mathrm{ABC}$ and human induced pluripotent stem cell-derived neuroepithelial cells promote tissue repair in an animal model of spinal cord injury. Biomed. Mater. 2018, 13, 024103. [CrossRef] [PubMed]

70. Hsieh, J.; Nakashima, K.; Kuwabara, T.; Mejia, E.; Gage, F.H. Histone deacetylase inhibition-mediated neuronal differentiation of multipotent adult neural progenitor cells. Proc. Natl. Acad. Sci. USA 2004, 101, 16659-16664. [CrossRef]

71. Ehashi, T.; Suzuki, N.; Ando, S.; Sumida, K.; Saito, K. Effects of valproic acid on gene expression during human embryonic stem cell differentiation into neurons. J. Toxicol. Sci. 2014, 39, 383-390. [CrossRef] [PubMed]

72. Chu, W.; Yuan, J.; Huang, L.; Xiang, X.; Zhu, H.; Chen, F.; Chen, Y.; Lin, J.; Feng, H. Valproic acid arrests proliferation but promotes neuronal differentiation of adult spinal NSPCs from SCI rats. Neurochem. Res. 2015, 40, 1472-1486. [CrossRef] [PubMed]

73. Abematsu, M.; Tsujimura, K.; Yamano, M.; Saito, M.; Kohno, K.; Kohyama, J.; Namihira, M.; Komiya, S.; Nakashima, K. Neurons derived from transplanted neural stem cells restore disrupted neuronal circuitry in a mouse model of spinal cord injury. J. Clin. Investig. 2010, 120, 3255-3266. [CrossRef] [PubMed]

74. Mandai, M.; Homma, K.; Okamoto, S.; Yamada, C.; Nomori, A.; Takahashi, M. Adequate time window and environmental factors supporting retinal graft cell survival in rd mice. Cell Med. 2012, 4, 45-54. [CrossRef]

75. Yoshikawa, T.; Samata, B.; Ogura, A.; Miyamoto, S.; Takahashi, J. Systemic administration of valproic acid and zonisamide promotes differentiation of induced pluripotent stem cell-derived dopaminergic neurons. Front. Cell. Neurosci. $2013,7,11$. [CrossRef] [PubMed]

76. Choudhury, M.E.; Moritoyo, T.; Yabe, H.; Nishikawa, N.; Nagai, M.; Kubo, M.; Matsuda, S.; Nomoto, M. Zonisamide attenuates MPTP neurotoxicity in marmosets. J. Pharmacol. Sci. 2010, 114, 298-303. [CrossRef]

77. Sonsalla, P.K.; Wong, L.Y.; Winnik, B.; Buckley, B. The antiepileptic drug zonisamide inhibits MAO-B and attenuates MPTP toxicity in mice: Clinical relevance. Exp. Neurol. 2010, 221, 329-334. [CrossRef] 
78. Yokoyama, H.; Yano, R.; Kuroiwa, H.; Tsukada, T.; Uchida, H.; Kato, H.; Kasahara, J.; Araki, T. Therapeutic effect of a novel anti-parkinsonian agent zonisamide against MPTP (1-methyl-4-phenyl-1,2,3,6-tetrahydropyridine) neurotoxicity in mice. Metab. Brain Dis. 2010, 25, 305-313. [CrossRef]

79. Costa, C.; Tozzi, A.; Luchetti, E.; Siliquini, S.; Belcastro, V.; Tantucci, M.; Picconi, B.; Ientile, R.; Calabresi, P.; Pisani, F. Electrophysiological actions of zonisamide on striatal neurons: Selective neuroprotection against complex I mitochondrial dysfunction. Exp. Neurol. 2010, 221, 217-224. [CrossRef]

80. Yagi, H.; Ohkawara, B.; Nakashima, H.; Ito, K.; Tsushima, M.; Ishii, H.; Noto, K.; Ohta, K.; Masuda, A.; Imagama, S.; et al. Zonisamide enhances neurite elongation of primary motor neurons and facilitates peripheral nerve regeneration in vitro and in a mouse model. PLoS ONE 2015, 10, e0142786. [CrossRef]

81. Miyawaki, Y.; Samata, B.; Kikuchi, T.; Nishimura, K.; Takahashi, J. Zonisamide promotes survival of human-induced pluripotent stem cell-derived dopaminergic neurons in the striatum of female rats. J. Neurosci. Res. 2020, 98, 1575-1587. [CrossRef] [PubMed]

82. Sawada, H.; Ibi, M.; Kihara, T.; Honda, K.; Nakamizo, T.; Kanki, R.; Nakanishi, M.; Sakka, N.; Akaike, A.; Shimohama, S. Estradiol protects dopaminergic neurons in a MPP+ Parkinson's disease model. Neuropharmacology 2002, 42, 1056-1064. [CrossRef]

83. Bains, M.; Roberts, J.L. Estrogen protects against dopamine neuron toxicity in primary mesencephalic cultures through an indirect P13K/Akt mediated astrocyte pathway. Neurosci. Lett. 2016, 610, 79-85. [CrossRef] [PubMed]

84. Callier, S.; Morissette, M.; Grandbois, M.; Pélaprat, D.; Di Paolo, T. Neuroprotective properties of $17 \beta$-estradiol, progesterone, and raloxifene in MPTP C57Bl/6 mice. Synapse 2001, 41, 131-138. [CrossRef] [PubMed]

85. Aguirre-Vidal, Y.; Morales-Montor, J.; Gómez de León, C.T.; Ostoa-Saloma, P.; Díaz-Zaragoza, M.; Montes, S.; Arteaga-Silva, M.; Monroy-Noyola, A. Protection induced by estradiol benzoate in the MPP+ rat model of Parkinson's disease is associated with the regulation of the inflammatory cytokine profile in the nigro striatum. J. Neuroimmunol. 2020, 349. [CrossRef]

86. Bourque, M.; Morissette, M.; Sweidi, S. Al; Donatella Caruso; Melcangi, R.C.; Paolo, T. Di Neuroprotective Effect of progesterone in MPTP-treated male mice. Neuroendocrinology 2016, 103, 300-314. [CrossRef]

87. Samantaray, S.; Das, A.; Matzelle, D.C.; Yu, S.P.; Wei, L.; Varma, A.; Ray, S.K.; Banik, N.L. Administration of low dose estrogen attenuates persistent inflammation, promotes angiogenesis, and improves locomotor function following chronic spinal cord injury in rats. J. Neurochem. 2016, 137, 604-617. [CrossRef]

88. Siriphorn, A.; Chompoopong, S.; Floyd, C.L. $17 \beta$-Estradiol protects Schwann cells against $\mathrm{H}_{2} \mathrm{O}_{2}$-induced cytotoxicity and increases transplanted Schwann cell survival in a cervical hemicontusion spinal cord injury model. J. Neurochem. 2010, 115, 864-872. [CrossRef]

89. Namjoo, Z.; Moradi, F.; Aryanpour, R.; Piryaei, A.; Joghataei, M.T.; Abbasi, Y.; Hosseini, A.; Hassanzadeh, S.; Taklimie, F.R.; Beyer, C.; et al. Combined effects of rat Schwann cells and $17 \beta$-estradiol in a spinal cord injury model. Metab. Brain Dis. 2018, 33, 1229-1242. [CrossRef] [PubMed]

90. Namjoo, Z.; Mortezaee, K.; Joghataei, M.T.; Moradi, F.; Piryaei, A.; Abbasi, Y.; Hosseini, A.; Majidpoor, J. Targeting axonal degeneration and demyelination using combination administration of $17 \beta$-estradiol and Schwann cells in the rat model of spinal cord injury. J. Cell. Biochem. 2018, 119, 10195-10203. [CrossRef]

91. Nishimura, K.; Doi, D.; Samata, B.; Murayama, S.; Tahara, T.; Onoe, H.; Takahashi, J. Estradiol facilitates functional integration of iPSC-derived dopaminergic neurons into striatal neuronal circuits via activation of integrin $\alpha 5 \beta 1$. Stem Cell Rep. 2016, 6, 511-524. [CrossRef] [PubMed]

92. Bender, R.A.; Zhou, L.; Wilkars, W.; Fester, L.; Lanowski, J.S.; Paysen, D.; König, A.; Rune, G.M. Roles of 17ß-estradiol involve regulation of reelin expression and synaptogenesis in the dentate gyrus. Cereb. Cortex 2010, 20, 2985-2995. [CrossRef]

93. Sekine, K.; Kawauchi, T.; Kubo, K.I.; Honda, T.; Herz, J.; Hattori, M.; Kinashi, T.; Nakajima, K. Reelin controls neuronal positioning by promoting cell-matrix adhesion via inside-out activation of integrin $\alpha 5 \beta 1$. Neuron 2012, 76, 353-369. [CrossRef]

94. Würth, R.; Thellung, S.; Bajetto, A.; Mazzanti, M.; Florio, T.; Barbieri, F. Drug-repositioning opportunities for cancer therapy: Novel molecular targets for known compounds. Drug Discov. Today 2016, 21, 190-199. [CrossRef]

95. Turanli, B.; Grøtli, M.; Boren, J.; Nielsen, J.; Uhlen, M.; Arga, K.Y.; Mardinoglu, A. Drug repositioning for effective prostate cancer treatment. Front. Physiol. 2018, 9, 500. [CrossRef] [PubMed]

96. Guhr, A.; Kobold, S.; Seltmann, S.; Seiler Wulczyn, A.E.M.; Kurtz, A.; Löser, P. Recent trends in research with human pluripotent stem cells: Impact of research and use of cell lines in experimental research and clinical trials. Stem Cell Rep. 2018, 11, 485-496. [CrossRef] [PubMed]

97. Yamanaka, S. Pluripotent stem cell-based cell therapy-Promise and challenges. Cell Stem Cell 2020, 27, 523-531. [CrossRef]

98. Dazert, P.; Suofu, Y.; Grube, M.; Popa-Wagner, A.; Kroemer, H.K.; Jedlitschky, G.; Kessler, C. Differential regulation of transport proteins in the periinfarct region following reversible middle cerebral artery occlusion in rats. Neuroscience 2006, 142, 1071-1079. [CrossRef]

99. Ginsberg, G.; Hattis, D.; Russ, A.; Sonawane, B. Pharmacokinetic and pharmacodynamic factors that can affect sensitivity to neurotoxic sequelae in elderly individuals. Environ. Health Perspect. 2005, 113, 1243-1249. [CrossRef]

100. Schwartz, J.B. The current state of knowledge on age, sex, and their interactions on clinical pharmacology. Clin. Pharmacol. Ther. 2007, 82, 87-96. [CrossRef]

101. Vanhaelen, Q.; Mamoshina, P.; Aliper, A.M.; Artemov, A.; Lezhnina, K.; Ozerov, I.; Labat, I.; Zhavoronkov, A. Design of efficient computational workflows for in silico drug repurposing. Drug Discov. Today 2017, 22, 210-222. [CrossRef] [PubMed] 